\title{
The Southern-Most Ivy: Princeton University from Jim Crow Admissions to Anti-Apartheid Protests, 1794-1969
}

\section{Stefan M. Bradley}

At the beginning of the twentieth century, the brother of famed black Renaissance man and former resident of the town of Princeton, Paul Robeson, attempted to apply to Princeton University. The university president at the time, Woodrow Wilson, refused his application even after the town of Princeton's most popular black minister, William Drew Robeson of Witherspoon Street Presbyterian Church, appealed to Wilson personally on behalf of his son. Historically, black ministers have acted as liaisons between black and white communities, and that had typically been evident in the town of Princeton. In the case of the Reverend Robeson's son's application for admission, the tacit relationship between the black clergy and white institutional power meant nothing. Paul Robeson, for the rest of his life, resented Princeton University for its treatment of his brother and father. Princeton, as a northern town and an elite university, was as segregated as any place below the Mason-Dixon Line for much of its history. Although black students met with cold reception when they arrived at the seven other American Ivy League universities, they could at least attend those schools. African American students could not attend Princeton in earnest until the middle of the twentieth century. For that reason, Princeton University earned the unique reputation of being what one might describe as the southern-most Ivy. ${ }^{1}$ In studying the experience of black people with Princeton University - a premiere institution of education - one can better understand how engulfing racism was in this nation's history. By neglecting the histories of African Americans at Ivy League universi- 
ties, scholars have failed to acknowledge the expanse of the struggle for black freedom.

Those affiliated with Princeton University and other elite Ivy League schools can proudly say that their students, faculty, and administrators go on to literally lead the nation in terms of politics, culture, and economics. For instance, Princeton University presidents signed the Declaration of Independence and created the Fourteen Points Plan. One need not look any further than recent American presidents and Supreme Court justices for the contemporary influence of the Ivy League. ${ }^{2}$ Princeton affiliates continue to boast, as did Woodrow Wilson, while still a faculty member, in 1896, that their university is "in the nation's service and in the service of all nations." ${ }^{.3}$ In essence, Ivy League universities aim to represent the best and most powerful aspects of America. The selection standards and curricula established by Ivy institutions influence other institutions of higher education around the nation and world. ${ }^{4}$ Although Princeton University and its peers are among the oldest and leading American universities, like most other institutions of higher learning, they had to be led into a new era of freedom for black people and social justice. In the twentieth century, students and progressive-minded school officials influenced by social movements, led to Princeton's acceptance of black students, the establishment of its Black Studies curriculum, and the school's stand against apartheid South Africa.

Recent works have dealt with the relationship of universities to black people. Donald Downs described the rebellious black students who armed themselves in demonstrations at Cornell University in 1969. Wayne Glasker and this author wrote about the relationship of Ivy League universities (Penn and Columbia) to black neighborhoods in Philadelphia and Harlem. Scholars such as Joy Ann Williamson, Fabio Rojas, and Peter Wallenstein have described the role of black students in changing policy at public universities. Although there is rich scholarly literature surrounding Princeton University in general, there is surprisingly little written about Princeton and its historic relationship with black people. Carl Fields, who came to Princeton as an administrator in 1964, published his memoirs of his tenure at Princeton. Recently, Melvin McCray, a black alumnus, produced a documentary entitled, "Looking Back: Reflections of Black Princeton Alumni." Jerome Karabel, in The Chosen (2005), discussed Princeton's struggle to attract a certain type of student that did not include African Americans and even Jews at one point. ${ }^{5}$ Several articles in Princeton University publications have focused on the arrival of black students to campus, but the evolution from black admissions to the campus activism of black students remains generally absent.

When scholars of the Civil Rights and Black Power Movements discuss the protests and demonstrations that took place in the state of New Jersey, they typically mention the unrest that occurred in Newark during the race riots of 1967.6 Some remember the student protests that occurred at Rutgers University during the period. ${ }^{7}$ Less attention has been given to the student demonstrations that took place on the beautifully landscaped campus of Princeton University in the late 1960s. Although there were no snipers atop buildings and no tanks maneuvering 
through campus, students at Princeton took up the cause of the Black Freedom Movement. The fact that students at one of the nation's most prestigious institutions of higher learning chose to sacrifice their almost guaranteed American success is worthy of note. Inasmuch, this essay seeks to illuminate the role that students, particularly African American students, played in transforming Princeton University. Moreover, it illustrates the impact that young people have had on the policy decisions of American institutions. By the end of the 1960s, black students, with the assistance of liberal university officials, were able to improve Princeton University's relationship with black people domestically and abroad.

\section{Princeton's Desegregation}

Of its Ivy League counterparts, Princeton, in terms of culture, was certainly closest to the American Old South that fostered strict racial separation and blatant stereotypes. Several of the university's early trustees owned slaves, and during the antebellum period nearly half of the student body consisted of southerners, which was more than other Ivy League institutions at the time. One of the university's presidents, John MacLean, held membership with the American Colonization Society that encouraged the deportation of black people for the sake of the nation. In that sense, the school had a long, entangled history with black people. ${ }^{8}$

As did many of the Ivy League institutions, Princeton originated with unofficial ties to religious groups. The Presbyterian Church helped to establish the College of New Jersey, which later became Princeton University. ${ }^{9}$ Adhering to the mission of Christianity, the college trained men (Princeton University did not become co-educational until 1969) to enter the Presbyterian ministry. By 1774, two African students attended Princeton Theological Seminary (which was technically separate from the university) for "preparatory work" preceding a trip to Africa for missionary work. ${ }^{10}$ Although enrolled for several years, the aforementioned students, Bristol Yamma and John Quamine, left without graduating. The September 25, 1792 minutes of Princeton's Board of Trustees, reveals a recommendation that a free black man, John Chavis study with the president of the university, John Witherspoon. ${ }^{11}$ After studying with Witherspoon, Chavis later became a Presbyterian minister in North Carolina. Incidentally, two centuries later John Chavis's descendant Benjamin Chavis became the executive director of the National Association for the Advancement of Colored People (NAACP) and eventually a minister with the Nation of Islam. ${ }^{12}$

The town of Princeton allowed slavery, and slaves were present on the Princeton University's campus. One Princeton student turned in a black man he recognized in the town of Princeton for violating the Fugitive Slave Act of $1793 .{ }^{13}$ A relative of former university president John Witherspoon eventually paid to manumit the escaped slave, but the culture of the university supported those who favored the peculiar institution. As one observer noted about its relationship to black people, "she [Princeton] has not measured up to the Christian standard in 
her attitude." The observer claimed that this owed largely "to the proslavery spirit ... caused by Southern slave holders, who settled in and about the place."14

In the years after slavery ended, Princeton continued to confront challenges regarding the presence of black people on campus. During Reconstruction black men came to campus not as slaves but as potential students. By 1876, four black men were attending Princeton's Theological Seminary. As was custom, the university permitted seminary students to attend courses. But when one of the black students, Daniel Culp, entered a psychology course on Princeton's campus, some of the white students rebelled. A southern newspaper reported the presence of this black student upset "some representatives from the "Sunny South" in such a way that the southerners chose to exit the lectures. ${ }^{15}$ Subsequently, several of those southern white students left the university in protest of the black student's presence. The rebelling students later requested to be readmitted when the university president refused to expel the black student ${ }^{16}$ Twenty years later, Alexander Dumas Watkins, a black man, acted as an informal instructor for several years until his death in 1903 in the department of histology at Princeton as the assistant of the geologist, Professor William Libbey.

At the turn of the century, President of Princeton Woodrow Wilson ensured that the institution would remain exclusively white. Reared as a southerner in a former slave holding family, Wilson frequently embraced racial stereotypes associated with African Americans and disregarded black people as innately inferior beings. A fellow Princeton alumnus remembered Wilson's great ability to tell "darky" jokes. ${ }^{17}$ Like many southerners of the period, Wilson strongly opposed the mixing of races on the grounds that it would taint the pure white race. In 1904, Wilson discussed the potential presence of black students at Princeton: "While there is nothing in the law of the University to prevent a negro's entering, the whole temper and tradition of the place are such that no negro has ever applied for admission, and it seems extremely unlikely that the question will ever assume a practical form." 18

Five years later, a black student from the Virginia Theological Seminary and College wrote to Wilson, stating "I want so much to come to your school at Princeton." ${ }^{\prime 19}$ Wilson quickly referred the letter to his secretary, who replied on the president's behalf that the aspiring student should either attend a university in the South or apply to universities like Harvard, Dartmouth, or Brown, where he would be more welcome. ${ }^{20}$ It came as no surprise to many when Wilson, who in 1912 was elected president of the United States, re-segregated all government offices or when he endorsed the glorification of the Ku Klux Klan in D.W. Griffith's 1915 film Birth of a Nation (1915). Furthermore, Wilson, who had received a doctorate in government and history from Johns Hopkins, claimed that the movie that so demeaned black citizens was like "history written in lightning." The irony of the matter was that Wilson, while president of Princeton and the nation, pushed to advance democracy on other social grounds while upholding white supremacy. He waged a campaign to change Princeton's class caste system by attempting to abolish the exclusive eating clubs. The clubs provided 
many of the social activities on campus, but they also denied students of lower economic ranks. Wilson believed it was wrong to turn away students because of their economic class, but did not go a step further by removing de facto Jim Crow barriers to the admission of black students.

Wilson had support from his fellow alumni. As one alumnus put it, "Princeton must remain the shining citadel of white supremacy and set an example for all of the world to see of the tolerance and intelligence of the white man." ${ }^{21}$ Indeed, to state that there were no African Americans on Princeton's campus during the first part of the twentieth century would be fallacious. Black cooks prepared food for the exclusive eating clubs (as was characteristic of eating facilities at nearly all the Ivy institutions). At least one black man acted as a servant for one of Princeton's premiere constitutional scholars. ${ }^{22}$ Until the 1940s, those were some of the only black people at the university. The conspicuous presence of African Americans almost exclusively in the role of cooks and servants was reminiscent of images from the institutions of the Old South. A Dartmouth College president in the 1920s claimed that at Brown, Penn, Cornell, Dartmouth, and Harvard, few black students were admitted but they could participate in the bulk of college life. At Yale, he explained, black students were admitted but did not have the opportunity to socialize with their white classmates. The Dartmouth president observed that with regard to Princeton University and black students, however, "the color line is drawn with the utmost rigidity and the [black] man [is] not even given access to the curriculum." 23

The U.S. military is as steeped in tradition as any American institution; yet, the military in some ways outpaced the rest of American society as it concerned racial progress. In the case of Princeton, it may have actually taken the military to change the admission practices of the Ivy League institution. The U.S. Navy, in partnership with Princeton University, instituted the V-12 program on campus. The program allowed naval cadets to take college courses in hopes of increasing the number of eligible officers for service during war time. ${ }^{24}$ In 1945, the partnership resulted in admission of four black naval cadets. The efforts of northern civilian activists of the NAACP, who waged the "Double V(ictory)" campaign during WWII, also had some influence on Princeton's policies of allowing black students as undergraduates. Those activists sought to defeat fascism abroad and to dismantle racism at home. ${ }^{25}$ With black servicemen attending Princeton, they achieved both goals.

During World War II, some Princeton alumni could not justify their university's rejection of American citizens who wanted to attend an American university, while purporting to make the world safe for democracy and rescuing Jewish victims from Nazi concentration camps. Norman Thomas, an alumnus of the class of 1905, explained that Princeton men claim that their alma mater "is for the nation's service" and is "dedicated to 'democracy,' ... to 'the liberal spirit' - in complete opposition to fascist standards. Yet Princeton maintains a racial intolerance almost worthy of Hitler." Thomas decried the fact that "a race which is furnishing an increasing number of artists, musicians, scientists, can 


\section{Stefan M. Bradley}

send no man be he as versatile as Paul Robeson ... to the fourth oldest American institution of learning." ${ }^{26}$ Incidentally, Robeson attended Rutgers University in New Jersey. Thomas chided that "Negroes may go to, and make good in Harvard, Yale, Columbia, ... indeed all leading American colleges and universities except Princeton." ${ }^{27}$ Between 1928 and 1948, Thomas ran as a Socialist candidate for president of the United States. He also received an honorary Doctor of Laws degree from Princeton..$^{28}$ Another alumnus echoed Thomas's sentiment. Ralph J. Reiman, from the class of 1935, stated that "Negro students have much to offer Princeton and Princeton has much to offer Negro students. ${ }^{.29}$ Reiman eventually graduated Harvard Law and served as a U.S. Army intelligence officer during World War II. ${ }^{30}$

Two students from the class of 1945, W.F. Weaver and J.L. Webb, exclaimed that "to make democracy come true we must begin at home." ${ }^{31}$ For Weaver and Webb, manifesting democracy at home meant allowing black students to matriculate at the university. Another student hoped for racial progress at the institution:

Princeton, a leading university with a strong Southern tradition, could seize this opportunity to take the lead in working out the only alternative to eventual revolution - that alternative is [racial] cooperation. ... Lest we forget, Princeton is the last of the leading institutions outside the deep South which still adheres to this faith in racial superiority. ${ }^{32}$

Although few in number, there was a contingent of concerned Princeton affiliates that pressured the university to evolve.

In some areas of post-World War II American society, the race problem tempered. Jackie Robinson signed a contract with the Brooklyn Dodgers, President Harry Truman issued Executive Order 9981 that desegregated the U.S. military, the Supreme Court ruled against the segregation of public interstate transportation and restrictive covenants. Robinson's entry into the major leagues, the desegregation of the armed forces, and the rulings of the Supreme Court occurred because of the constant efforts of black citizens who wanted to ensure their nation lived out its creed. ${ }^{33}$

As U.S. officials and heroic American citizens made history, so too did one of the four naval cadets whom Princeton admitted in 1945. While on campus, these black student-sailors did not join the exclusive eating clubs and rarely socialized outside of class with their fellow white students. Despite the social isolation, in 1947, John L. Howard became the first African American to receive a bachelor's degree from the university. ${ }^{34}$ Howard, who had attended integrated schools in New York, noted that his was a "very mellow experience." He explained that he was not attending "traditional" Princeton University but rather "wartime Princeton" that catered to students from the military. ${ }^{35}$ Howard eventually became an orthopedic surgeon. By 1948, another black cadet, James Ward, also received a 
bachelor's degree. Ward eventually worked for the Texas Commission on Human Rights as an investigator and legal counsel. Another cadet, Melvin Murchison, became the first black athlete to play a varsity sport (football) at Princeton. The fourth black cadet, Arthur "Pete" Wilson, played two seasons of varsity basketball, and even acted as the team captain. ${ }^{36}$ It is interesting to note that those achieving black students who were admitted literally had to be "in the nation's service" to attend Princeton.

Some white veterans, who witnessed the service of black men during the war, also moved to alter Princeton's racial policies of admission. In 1946, several white soldier-students in coalition with several civilian-students formed an organization called the Liberal Union. In an attempt to enlighten the campus with respect to the abilities and equality of black people, the Liberal Union brought then NAACP executive director Walter White to campus to speak to the general student body. Sixty-two years later, Robert Rivers, a black observer from the town of Princeton, remembered the shameful treatment the executive director received upon arriving to campus. Rivers, who eventually attended and graduated from the university, recalled "the scene where Princeton [University] students taunted and threw snowballs at the NAACP executive director." The Walter White scene is notable on at least two levels. On the one hand, if Princeton were a place that pledged to forge the leaders of the future, it appeared that those future leaders had not yet matured. Indeed, heaving snowballs at an actual societal leader could be characterized as nothing more than juvenile. On the other hand, the fact that a dogged advocate of integration who happened to be black could speak on campus marked a shift in Princeton's history. ${ }^{37}$

Even if slow and incremental, Princeton's culture changed with the times. The first black undergraduate student that Princeton University admitted without impetus or assistance from the military was Joseph Ralph Moss. A resident of the town of Princeton, Moss arrived at the university in the fall of 1947. While he did not participate wholly in campus events, he did eventually join a campus eating club and even lived on campus at one point. The admissions officer who interviewed Moss noted that the student had a light complexion and a mother of "very high-grade." The officer further observed that Moss's brother, Simeon, had attended the graduate school as part of the G.I. Bill. Joseph Moss graduated with a bachelor's degree in $1951 .{ }^{38}$

Princeton desegregated in the immediate Post World War II era, though not out of sheer goodwill. An article in the Princeton Alumni Weekly pointed out that in 1947 , state legislators rewrote the state's constitution to explicitly prohibit racial discrimination. ${ }^{39}$ In doing so, state-funded institutions were required to adhere to the new policy regarding discrimination. Although Princeton was a private university, it did receive some funds from the state of New Jersey. Subsequently, Princeton more freely admitted black undergraduates.

As the university accepted more undergraduates, it also observed changes regarding faculty demographics. Princeton hired its first black tenure-track faculty member during this period. On July 30,1955 , the black newspaper 
the Newark Herald proclaimed that "one of the most glorious chapters in the history of Princeton was written ... when Dr. Charles T. Davis, a Negro, was appointed a member of the faculty of this famous University." ${ }^{40}$ Davis, 39 years old, had graduated from Dartmouth College and received a Ph.D. from New York University. A Walt Whitman scholar and former army officer, he arrived at Princeton to teach English. His arrival was indeed historic, but it seemed to cause less friction than the arrival of black students.

During the 1940s and 1950s, few black students (undergraduate or otherwise) attended Princeton. The situation changed, however, in the 1960s. By then, Princeton alumnus and faculty member Robert Goheen had become president of the university. Born in India the son of American Presbyterian missionaries, Goheen rose to the rank of Lieutenant Colonel in the U.S. Army during World War II. ${ }^{41}$ Goheen's worldview was somewhat more liberal than his predecessors. In terms of the university's relationship to black students, Goheen attempted to change the university's racially exclusionary image. In 1963, in a moment of clarity, he stated, "For the past decade, we have been terribly concerned with what we could do for students from underdeveloped countries. It took a shock (the civil rights crisis) to make us realize our problems at home." ${ }^{42}$ President Goheen authorized a tutorial program for mostly black youth in the nearby city of Trenton, which had a significant black poor and working-class population, as a long term approach to admitting more black students. ${ }^{43}$

The early 1960s saw further tentative admission of black students. One Daily Princetonian article noted that of the 1,202 applicants who were accepted for the 1963-1964 academic year, ten were black. Although the number of accepted African Americans was small, the article claimed that no black student had been accepted in 1953, 1954, and 1959. The article blamed the unfriendly nature of the town of Princeton and the university itself, as well as the "scarcity of qualified Negroes, which is slowly being corrected." ${ }^{44}$ To be sure, the town of Princeton had a history of segregation and discrimination against its black residents. The town's treatment of African Americans, however, did not mean that the university had to be unwelcoming. Incidentally, the article also noted that of the class entering the 1963-1964 school year, 20 percent were the sons of alumni. The article did not mention the qualifications of the legacy students.

Following the lead of Goheen, who recognized the significance of the Civil Rights Movement, Princeton's admissions office targeted black applicants. The director of admissions sent letters to 4,000 public and private high schools, notifying the school counselors of Princeton's "search for Negro applicants." The university also attempted to cultivate potential black students through the Trenton Tutorial Project that involved university students and faculty members tutoring mostly underprivileged and black students at the nearby high schools. In 1963, over 140 Princeton students assisted the more than two hundred Trenton students (a significant number of whom were black) who signed up for the project. 
Even as university officials encouraged the effort to racially diversify Princeton's campus, there remained students who still opposed integration. In March 1964, several university students created an organization called the Princeton Committee for Racial Reconciliation. Despite the progressive sounding title, the members of the all-white group believed that the best way for the races to reconcile was to remain segregated. The group's president, Marshall Smith, claimed the group represented the opinions of one third of the student population (in fact there were only fifteen members of the groups). "We just want to show that in the midst of all this sympathy for the Negro there exists some opposition on campus," Smith explained. "Segregationists are not going to give up by default." ${ }^{\text {"46 }}$ Hoping to contradict the "integrationist propaganda" to which Princeton students had been exposed, Smith's group pointed to the controversial book by Princeton alumnus Carelton Putnam, Race and Reason (1961), that attempted to confirm racial stereotypes regarding black people and to justify segregation. The segregationist group claimed that Putnam's work provided evidence of the ineffectiveness of social integration.

Taking advantage of the 1965 Higher Education Act, Princeton used a federal grant to re-establish a cooperative program with the nation's first college established for black students, Lincoln College in Pennsylvania. Like Princeton, Lincoln had early ties to the Presbyterian Church, and Lincoln's first president supported colonization as did several early Princeton trustees. In 1854, Princeton alumni helped to found the institution to educate black men, and the universities maintained a relationship throughout the years with Princeton men serving on Lincoln's faculty and the board of trustees. In 1965, the \$113,000 Higher Education Act grant allowed for a faculty and student exchange. Lincoln faculty came to Princeton to take graduate courses and teach specialized courses, while Princeton graduate students had the opportunity to teach at Lincoln. Moreover, Princeton students and faculty members gained access to Lincoln's African Studies collection. While select Lincoln faculty members had the chance to take advanced courses from Princeton, a critic of the exchange might have observed that the white Princeton students, acting as instructors, were able to "practice" on black Lincoln students and to exploit Lincoln's special collections for the advancement of their own research agendas. This allowed the white Ivy League students (who would benefit from Princeton's reputation) the chance to be in the forefront of a relatively new field of study. The exchange was hardly equal. Still, the president of Lincoln explained: "The benefits . . . to both faculty and students through [the] cooperative relationship between a great university such as Princeton and a small liberal arts college will be of incalculable" value. ${ }^{47}$

\section{Consequences of Desegregation}

With the Princeton administration continuing its desegregation effort, students dealt with the implications of the movement. Although a higher number of black students than ever before were attending Princeton, they did not always feel 


\section{Stefan M. Bradley}

welcome. Harvard Bell, sophomore in 1968, remembered Princeton as a "lonely" place where he felt at times "unwelcome" and "under attack." ${ }^{48}$ As it was, the arrival of black students set into motion a cultural experiment on Princeton's campus that was ultimately positive but at times troublesome.

By most accounts, 1968 was a year that stood out as both eventful and traumatic for the nation and the world. Popular leaders Martin Luther King, Jr. and Robert Kennedy were assassinated, while students and other activists railed against the escalated war effort in Vietnam and for youth empowerment. Some Ivy League university campuses, such as Columbia University, shut down in response to student rebellion against the university's ties to the Vietnam War, and, in the case of Columbia to student protests of what they viewed as racist policies concerning the expansion of the university. Princeton students opposed similar ties to the university's relationship with the Department of Defense. Indeed, Ivy League universities were not immune to the social unrest, riots, and uprisings that affected the rest of the nation. ${ }^{49}$ The Black Power Movement had reached college campuses along with a more militant brand of African American students. The result was a push for a black identity on campus, which often led to demands for Black Studies courses and programs. ${ }^{50}$ Yale University moved quickly to establish a program; Princeton, however, took a slower approach.

In 1968, Princeton University offered courses that focused on black history and culture. That year, Henry Drewry, a black man, became the director of the university's office of teacher placement and preparation. ${ }^{51}$ Drewry, who had taught in the town of Princeton's school district for fourteen years and as a lecturer on the university's campus, made history at Princeton by teaching the university's first Black Studies courses. He and his wife Cecelia offered two seminars, one covering "Black American Writers" and another dealing with "Afro-American History." Considering Princeton's past with regard to race relations, there was little surprise when news outlets noted that the courses were the first of their kind in Princeton's then 222 year history. Princeton had come a long way. It should also be noted, however, that Henry Drewry was teaching the seminars in addition to his teacher placement duties with the university. The dean of Princeton's college of arts and sciences stated that the introduction of the two courses would help the college in "establishing a more formal, comprehensive program relating to black culture." ${ }^{2} 2$

Despite the progress that the university made, Princeton still faced racial problems. In October 1968, black and white students confronted each other in a campus dormitory. Upset about the volume of music that white students played at a mixer, several black students who lived in the dormitory first complained to the dormitory director and then met the white residents in their room. The white residents, according to a university investigation, made several "racially offensive remarks" to the black students, who left and returned to the room with several more of their fellow black students. While in the white students' room, one of the black students used a knife to slash the stereo speakers. As the situation escalated, nearly fifty students altogether participated in the controversy, 
but there is no record of violence. To be sure noise complaints are common in residential settings. While race may not have been at the root of the conflict, certainly race became an issue when the white residents, who hosted the party, used epithets to address the black students. Race may have been a factor in the dormitory director's refusal to reprimand the noisemakers or neglect of the situation altogether. None of the students faced criminal charges. ${ }^{53}$

\section{$\mathrm{ABC}$ and Princeton's Black Identity}

From the 1940s to the early 1960s black students struggled to even matriculate at Princeton; by the late 1960s, however, Princeton's black students had established a unique identity for themselves. Because of isolation on campus and a growing black consciousness, black students bonded. ${ }^{54}$ Out of that bond, in 1967, black students established the Association of Black Collegians (ABC) as a local campus organization. With university funding, the new group attempted to aid in the social and academic acclimation of black students and to initiate dialogue with the surrounding black communities of Princeton and Trenton. The group's founders viewed ABC "as a bloc, effecting policy both now and in the future." Taking on the cadence of Black Power rhetoric, an early coordinator explained that "when something is going to be done, we are the ones who are going to have to do it." ${ }^{55}$ In response to the abysmal number of black students enrolled at Princeton, the members of the organization took up that ethic, taking it upon themselves to visit predominantly black high schools around the country during the winter breaks to recruit for the university. ${ }^{56}$

In addition to their high school visitation program, the members of $\mathrm{ABC}$ acted as on-campus hosts to potential black students. In February 1968, Princeton, in conjunction with $\mathrm{ABC}$ and Jim Brown's Negro Industrial and Economic Union, sponsored twenty urban youth who visited Princeton. $\mathrm{ABC}$ members brought the potential students to the admissions office, where they underwent interviews. One of the most important aspects of $\mathrm{ABC}$ 's approach to recruitment was the fact that the members of the college group provided examples of black students who readily navigated what many black youth called the "system." One of the only black admissions officials explained, "[the visiting young people] learned that 'they could have higher education without losing their own black identity."

Because the members of $\mathrm{ABC}$ took it upon themselves to ensure that Princeton became an option for other black students, in 1968, President Goheen and the elite institution saw the fruits of the black student group's efforts. That school year, Princeton admitted seventy-six new black students while ninety-seven black men altogether attended Princeton, which marked a high for the university. ${ }^{58}$ Sociologist Jerome Karabel has recently argued that even more than the Civil Rights Movement of the South, the race riots and Black Power Movement of the North influenced the decision of Ivy League universities to admit black students. The universities, Karabel asserted, were concerned that the rage of the urban poor might be waged on the elite white institutions of higher education if they did 
not attempt to improve ghetto circumstances by admitting students. ${ }^{59}$ As a result, black students, some of whom had witnessed rioting in their neighborhoods and were sympathetic to the tenets of Black Power, arrived on Princeton's campus.

Although very able as a recruiting organization, $\mathrm{ABC}$ 's larger agenda extended further. The group saw itself as part of the tradition of black students and youth who changed society for the better. With that in mind, ABC, with the help of black administrator Carl Fields, organized a national conference that involved students from over forty universities and colleges.$^{60}$ Under Fields's tutelage, the members of $\mathrm{ABC}$ focused on the future of the "Negro undergraduate" with seminars concerning education, economics, politics, and community organizations.

When Martin Luther King, Jr. was assassinated on April 4, 1968, the members of $\mathrm{ABC}$ led students in a boycott of classes. ${ }^{61} \mathrm{In}$ an emotional letter to the school newspaper, $\mathrm{ABC}$ expressed its sorrow and anger with the civil rights leader's murder. "It is not one man, however guilty he may be, that murdered Dr. King. Rather, it is the society as a whole that we indict," stated ABC. The group lamented that because of the "injustice of this society, black America is under no constraints to obey white America's hypocritical laws. It is in America's best interests that the black man revolts." ${ }^{22} \mathrm{ABC}$ declared that "No black student will attend classes! No black student will work any job!" In order to avoid controversy, President Goheen provided his endorsement for the group's act. ${ }^{63}$

\section{Princeton's Anti-Apartheid Movement}

As members of $\mathrm{ABC}$, black students on campus looked beyond themselves toward the larger Black Freedom Movement. The members of ABC fell in line with other student activists. Following the lead of Malcolm X, the Student NonViolent Coordinating Committee (SNCC) in the late 1960s sought to tie the struggle of black people in the United States to that of black people abroad. ${ }^{64}$ In taking a Pan-Africanist approach to the struggle, SNCC eventually called for an end to European colonization of African countries. As it was, black South Africans dealt daily with the impacts of colonization under apartheid - a racial caste system of governing that not coincidentally mirrored America's Jim Crow laws and culture.

While in the 1960s, many African Americans battled poverty and racism domestically, some black activists chose to denounce South Africa's racist policies. As the United States desegregated, South Africa further entrenched its racial caste system. Organizations like the American Committee on Africa, which enjoyed the support of black fraternal and sorority groups, the National Council of Negro Women, the Brotherhood of Sleeping Car Porters, the Congress of Racial Equality (CORE), the National Association for the Advancement of Colored People (NAACP), the National Urban League, and the Southern Christian Leadership Conference (SCLC) registered their objections of apartheid. In 1962, the Committee issued a resolution calling for black Americans to protest 
the mistreatment of Africans abroad, and three years later the Committee made recommendations to the federal government regarding apartheid. ${ }^{65}$ The United Nations general assembly also brought apartheid to the forefront in the early 1960s. Black politicians like Congressman Charles Diggs brought up the issue of apartheid to US political officials who had previously turned a blind eye to South African policies. ${ }^{66}$ Tennis star Arthur Ashe was another who loudly protested against apartheid, as did the scholars John Henrik Clarke and C.L.R. James. Abroad, scholars in Britain opposed apartheid in a boycott of South Africa ${ }^{67}$ Other anti-apartheid activists included the American student/athlete members of the Olympic Project for Human Rights (OPHR) led by former athlete and educator Harry Edwards. ${ }^{68}$

The members of the OPHR were not the only students to oppose what they viewed as immoral policy in South Africa. In 1968, black Princeton students, in alliance with white radical students, protested against Princeton University's investment policy with regard to South Africa. In doing so, the student activists preceded the American collegiate anti-apartheid movement by nearly two decades ${ }^{69}$ Furthermore, they set the stage for what would become a major battle for justice within the US Congress in the 1970s and 1980s. Princeton students envisioned their anti-apartheid campaign as part of the international struggle for black freedom and the Pan-African Movement.

In April 1968, students at Princeton proposed that the university not invest any future funds into companies associated with the apartheid-sanctioning governments of South Africa and Mozambique. While students at Yale demanded a Black Studies program, and those at Columbia demanded that their university show more respect to its black neighbors of Harlem, students at Princeton insisted that the university divest $\$ 127$ million from its financial portfolio. ${ }^{70}$ Armed with the knowledge of history concerning segregation and apartheid, the students took action. After $\mathrm{ABC}$ members and other anti-apartheid students marched at the Woodrow Wilson School of International Affairs-a school named for a man who reinstituted the American version of apartheid in governmental offices-Princeton attempted to diffuse the rising controversy. University officials formed a committee that included administrators, faculty members, and students to study the impacts of the school's investments and the efficacy of divestment. In January 1969, the committee issued a report that claimed that the university had no investments in companies that "directly support the governments of southern Africa, or that have substantial operation in the region." Furthermore, the committee reported, "the designated companies [that the students had identified] derive an average less than one per cent of their sales and profits from southern Africa." 71

The student members of the committee refused to endorse the report that explained that the university, by divesting, stood to lose the equivalent of 10 percent of the university's educational budget. Doing so, according the report, would necessitate curtailing important programs "such as urban studies," that make a direct contribution to the cause of racial justice such as the active recruit- 
ment and granting of scholarship aid to more black students, the establishment of closer working relationships with organizations in New Jersey concerned with racial problems, and other programs such as the summer program for the disadvantaged youth." Asserting that divestment would be mostly a "symbolic gesture," the report suggested that such a gesture "would be a heavy price to pay." 72

The report placed the student opponents of apartheid in a moral conundrum of sorts. If the students chose to push forward with their protests, then they might have won a victory for the image of the university and against what they perceived as evil. At the same time, by continuing their efforts, the protesting students, ran the risk of losing funding used to attract and cultivate potential black students. If the students abandoned their push against the university's financial ties to apartheid South Africa and Mozambique, they became implicated in a relationship they believed was immoral. At risk, if the university acceded to the students' requests, was the financial stability of the institution. Essentially, the authors of the report constructed a scenario where only black people abroad or black people domestically could be helped, but not both at the same time.

Presenting a potential slippery slope regarding the negative impacts of divesting, the report speculated about the precedent that could be set as a result. It stated:

If a policy of using moral, social, or political criteria in investment in a number of different instances, including 'munitions makers, companies with 'unfair' labor practices, companies dealing with discriminatory unions, companies with investments in Portugal, companies doing business with communist countries, etc. ... No company is completely free of connections that might be morally-politically-socially objectionable to a significant part of the University community. ${ }^{73}$

Such a burden would be too much for an educational institution, argued the report. The problem with that argument was that Princeton was not just an educational institution but also a mill for the nation's future leadership. What lessons were those leaders to learn from the report's stance on the university's tie to apartheid?

By March 1969, the Princeton students (mostly black), who formed the group United Front, wondered if their university could afford to be a moral institution with regard to racism. President Goheen attempted to address the concerns of the students. As a matter of policy, he stated that Princeton "will not hold securities in companies which do a primary amount of their economic activity in South Africa." ${ }^{\prime 74}$ Goheen noted that doing so constituted an "unusual commitment on the part of this, or indeed any, university." The president also acknowledged the important contribution of the black graduate students, who sat on the committee to study the apartheid issue. He then pointed to the fact that the faculty voted overwhelmingly to reject gifts to the university from companies "doing a 
primary amount of their business in southern Africa," and that he would recommend that the trustees adopt the policy. In addition, he pledged that Princeton would work with any other educational institutions that stood against apartheid, and the university did follow through on Goheen's pledge.

Lastly, the president reassured the students who worried about the original report's suggestion that changes in the university's investment policies could lead to cuts in funding for the recruitment of black students. He expressed great respect for the "depth, intensity, and nature of concerns which moved the United Front" and associated black students who pushed the issue. "We can and will do more to enable all our students - black and white - to study and learn from the Afro-American experience. We can and will extend our current efforts to add more black faculty, students, and staff to the University community. We can and will support and encourage the efforts of students, faculty, and staff to work with local community groups on problems of mutual concern," proclaimed President Goheen. ${ }^{75}$ To bolster the president's proclamations, in early March 1969, the Princeton faculty voted to approve an Afro-American studies program for the university. ${ }^{76}$ As the story about the university's ties to apartheid became national news, Goheen's approach to the stirring controversy was open for scrutiny. ${ }^{77}$

Although positive in tone, the president's message did not provide solace to the anti-apartheid students. On the morning of March 11, 1969, ABC launched what it would later call a "symbolic gesture" by staging a sit-in on Princeton's campus. Fifty-five black student members of ABC and five white members of the campus chapter of the national New Left organization, Students for a Democratic Society (SDS), entered the New South building that housed the university's administrative offices and chained the doors shut. Although not adversarial, $\mathrm{ABC}$ and SDS had not worked especially closely on any projects before the demonstration. In addition to ABC and SDS, the Pan-African Student Association and the New Jersey Committee for South Africa assisted in organizing the demonstration. As the sixty students demonstrated inside the buildings, fifty others (mostly SDS members) marched outside the hall. An ABC leader, Jerome Davis, stated, "We have taken this action to demonstrate our disgust as black people and as human beings." ${ }^{.78}$ The protesters pointed to, what they believed was "outright and admitted moral inconsistency of the university's commitment to mankind and the Government of South Africa." ${ }^{.79}$ The university committee that studied Princeton's ties to apartheid explained that to divest would be financially prohibitive. To that notion $\mathrm{ABC}$ declared, "Morality has no price" and refused to leave the building until it decided to do so ${ }^{80}$ When a reporter asked when that would be, an ABC representative replied, "When we leave, you'll know." 11

As was the case with the black students who occupied buildings at Columbia, Cornell, Howard, City College of New York, Rutgers, and so many other universities, the students at Princeton prepared well for their provisions during the demonstration. In the case of Princeton, activist Gerald Horne had learned from his firsthand observations of the spring 1968 uprising at Columbia University and the methods that black students used to sustain their offensive. Food was 
available in the building's cafeteria, and outside supporters offered assistance as well. In spite of the students' resolve, President Goheen pressured them to leave by pointing to the university's policy against taking over campus buildings. ${ }^{82}$ Furthermore, the president observed, "Many members of the university, members of the staff no less than students and faculty, are deeply troubled by this incident." The demonstration, he suggested, had "the potentiality of kindling latent antagonisms and provoking unconsidered counteraction." ${ }^{83}$ If the university did not divest, it also risked antagonisms and counteraction. Goheen declared, "The university cannot tolerate this seizure.... The Students face penalties up to and including dismissal." He added, "I don't believe in offering amnesty." The black student protesters had not asked for it.

Deliberate in their disobedience, the demonstrators operated on the first and seventh floors of the New South building. Those floors housed the university comptroller and payroll offices. The comptroller oversaw stock transactions, which included those with the companies that maintained relationships with apartheid-sanctioned governments, and the payroll offices issued checks to university employees. ${ }^{84} \mathrm{ABC}$ understood well that if the university was making the potential loss of money a main issue with regard to divestment, then black students would attempt to gain control of the issue by denying the university's access to money and the building. With that in mind, the demonstrators succeeded in stopping business in the building. In addition to halting the operations of the comptroller and payroll offices, the student activists impeded the progression of admissions applications as well. ${ }^{85}$

In a move similar to that of black student protesters at Columbia in 1968, ABC leadership asked the few white students who were in New South to leave so that the black students alone could express their disdain with the university's decision not to completely divest. ${ }^{86}$ In this way, these young activists employed Black Student Power by strategically using their race as a lever for power in negotiation with the university. The black demonstrators still enjoyed the support of SDS and the Third World Liberation front, which was another group of students that opposed Princeton's ties to the apartheid governments. If the ABC members believed that the university maintained racist ties to oppressive governments, then they wanted to be at the forefront of the movement to illuminate and break those ties. That sentiment mirrored that of black youth who demanded Black Power around the nation. For those black youth and Princeton's black demonstrators, it was necessary for black people to take the lead on issues that directly affected black people.

The goals of $\mathrm{ABC}$ were threefold. First, the members of $\mathrm{ABC}$ wanted to express their dismay with what they viewed as the president's inaction on the issue of South African divestment. Second, they wanted to highlight their commitment to raising the issue to the larger student body and all those who would listen. Third, ABC wanted to "sensitize as many individuals as possible to the need for serious moral commitment against racism throughout the world." ${ }^{87}$ 
When the world renowned New York Times picked up the story, it brought light to the students' struggle to sensitize the masses. ${ }^{88}$

At one point, there were hundreds of students and some faculty members outside the building observing the demonstration. Some disagreed with the tactics of the protesters but sympathized with the protesters' cause. One observing student said, "It's just not pragmatic" to take over buildings, and suggested that $\mathrm{ABC}$ "had to do something to keep the issue going." Another student opined, "Just in itself, it's tremendous. . . It was great to see something like that happening here, seeing this place break out of its complacent attitude." Regarding efforts of $\mathrm{ABC}$ and SDS, one student commented to a reporter that, "the ABC guys are really concerned and committed on this issue.... The SDS (Students for a Democratic Society) seems to be more of a bandwagon-type group." Still other students, frustrated with the disruption, unsuccessfully attempted to physically remove the demonstrators by attempting to open the doors. ${ }^{89}$

ABC evacuated New South twelve hours after the initial takeover. Group leaders claimed that the demonstrators did not leave for fear of punishment or arrest but rather because "the administration has already began to shift the emphasis on our protest away from [the] moral issues of South Africa to the legitimacy of our tactics." ${ }^{\text {90 }}$ Such a statement not only pointed up the seriousness of the students, but it also illustrated a strategy in black student activity whose origins dated back to the earliest parts of the modern Civil Rights Movement. That strategy was for demonstrators to focus onlookers' attention on the issue without making the methods a distraction. With that in mind, ABC leadership asserted that the takeover was only part of their larger movement. Although the students faced disciplinary consequences, they refused to recognize any punishment that the university imposed. "We cannot accept in good faith any so-called moral judgments made by such an immoral institution," ABC stated. Realizing that a single takeover was not enough to change policy, the student activists explained: "The battle for disinvestment will not be won quickly, but it will be won."'91

In a bold act, the student members of the joint student-faculty disciplinary committee refused to participate in proceedings that would punish the demonstrators. Eventually, five black demonstrators were punished just as the spring break began, and therefore, did not miss any classes or activities. Perhaps more students would have been punished, but the disciplinary committee claimed that it could not identify more of the participants. Although the black student demonstrators did not receive amnesty, they faced little to no punishment for their act of rebellion. ${ }^{92}$ Inasmuch, the university averted a potential crisis like those that occurred at universities around the nation. Princeton, unlike some of the other universities that experienced student disruptions, had voted to not give academic credit for Reserved Officer Training Corps courses and to establish an Afro-American studies program. The administration did not call police onto campus, which may have hastened or even provoked violence. Finally, the administration, particular, President Goheen, reasoned with students regarding their demands that Princeton 
become a more "moral" institution. At some institutions, administrators refused to reason or negotiate with respect to any university policy. ${ }^{93}$

\section{Conclusion}

While disruptive, the activity of those black students who demonstrated improved the university. Gerald Horne, a demonstrator at Princeton in the late 1960s, believed that black students had to act "to put the elites [powerful white institutional officials] on alert that we [students] were not inert." Indeed, in the twentieth century, black students moved from matriculation to activism at Princeton. Decades later, Horne noted that "activism is one of the best teachers." 94 this case, activism taught students that their presence alone was not an end goal and that they should think outside of themselves. In addition, activism taught an elite white institution to improve its relationship with black people domestically and abroad.

In the 1980s, students still protested against apartheid South Africa and the relationship of Princeton to the oppressive government. ${ }^{95}$ By the 1990 s students of color had a well-established identity on campus and participated in the school's various ethnic studies programs and departments. Today, black faculty members such as Cornell West, Kwame Appiah, and Toni Morrison frequently represent the university, when just sixty years before the prospect of a black person sitting on the faculty at Princeton would have seemed unthinkable. Black students make up approximately six percent of the current student population. Although Princeton University is still an elite and exclusive primarily white institution it is not unusual or controversial to see students of color. The institution that was once the southern-most Ivy, however, now houses one of the best Africana Studies Centers in the nation. It took the efforts of students - particular black students - to improve Princeton's reputation with regard to race and to move the institution closer to morality. In this case, morality meant admitting American citizens who happened to be black, including the experience of African Americans in the curriculum, and reconsidering the institution's financial support of apartheid. By matriculating and eventually protesting, black students have helped Princeton University to move closer to its goal of being "in the nation's service and in the service of all nations."

\section{Notes}

1. Paul Robeson, Here I Stand (Boston: Beacon Presss, 1988), 11; Paul Robeson, Jr., The Undiscovered Paul Robeson: An Artist's Journey, 1898-1939 (New York: Wiley Press, 2001), 5-6. For more insight into black life in Princeton, see Eslanda Robeson, Paul Robeson, Negro (London: Harper and Brothers, 1930); Lloyd Brown, The Young Paul Robeson: On My Journey Now (New York: Basic Books, 1997).

2. John Schwartz, "An Ivy-Covered Path to the Supreme Court," New York Times, 8 June 2009, http://www.nytimes.com/2009/06/09/us/politics/09ivy.html, accessed 13 November 2010.

3. "In the nation's service and in the service of all nations" is a line from an 1896 Woodrow Wilson speech while he was a faculty member at Princeton. Since then, Princetonians have used the phrase as an unofficial motto. http://www.princeton.edu/ mudd/exhibits/wilsonline/indn8nsvc. html, accessed 26 September 2011. 
4. For instance, shortly after Ivy League universities began looking to standardized tests to prevent class and social biases, other universities followed suit. See Nicholas Lehmann, The Big Test: The Secret History of the American Meritocracy (New York: Farrar, Straus, and Giroux, 1999). Similarly, several of the Ivy League universities maintained ties to the Department of Defense before many of the flagship universities of the states established relationships. See Jane Wilson, "Universities Act on the Institute for Defense Analysis," Bulletin of Atomic Scientists, May 1968, 40.

5. Donald Downs, Cornell '69: Liberalism and the Crisis of the American University (Ithaca: Cornell University Press, 1999); Wayne Glasker, Black Students in the Ivory Tower: African American Student Activism at the University of Pennsylvania, 1967-1990 (Amherst: University of Massachusetts Press, 2002); Stefan Bradley, Harlem vs. Columbia University: Black Student Power in the Late 1960s (Champaign: University of Illinois Press, 2009); Joy Ann Williamson, Black Power on Campus: The University of Illinois, 1965-1975 (Champaign: University of Illinois Press, 2003); Fabio Rojas, From Black Power to Black Studies: How a Radical Social Movement Became an Academic Discipline (Baltimore: Johns Hopkins University Press, 2007); Peter Wallenstein, ed., Higher Education and the Civil Rights Movement: White Supremacy, Black Southerners, and College Campuses (Gainesville: University of Florida Press, 2008); Ibram Rogers, "The Marginalization of the Black Campus Movement," Journal of Social History, vol. 42, no., 1, fall 2008, 175-182; Carl Fields, Black in Two Worlds (Princeton: Red Hummingbird Press, 2006); Jerome Karabel, The Chosen: The Hidden History of Admission and Exclusion at Yale, Harvard, and Princeton (Boston: Houghton Mifflin Harcourt, 2005).

6. See the outstanding documentary work of Marylou Tibaldo-Bongiorno, "Revolution '67," Borgiorno Productions, Inc., 2007. Also, there are several wonderful works discussing the northern Civil Rights and Black Power Movement. See Peniel Joseph, Waiting 'Til the Midnight Hour: A Narrative History of Black Power (New York: Henry Holt Company, 2006); Thomas Sugrue, Sweet Land of Liberty: The Forgotten Struggle of Civil Rights in the North (New York: Random House, 2008); Leonard Moore, Carl B. Stokes and the Rise of Black Political Power (Champaign: University of Illinois Press, 2003); Yohuru Williams, Black Politics/White Power: Civil Rights, Black Power, and Black Panthers (Maplecrest, New York: Brandywine, 2000); Matthew Countryman, The Up South: Civil Rights and Black Power in Philadelphia (Philadelphia: University of Pennsylvania Press, 2005); Jeanne Theoharis and Komozi Woodard, Groundworks: Local Black Freedom Movements in America (New York: New York University Press, 2005); and Brian Purnell, "Taxation without Sanitation is Tyranny': Brooklyn CORE Dumps Racial Discrimination on the Steps of Borough Hall," in Afro-Americans in New York Life and History, July 2007 (31:2), 61-88.

7. Richard McCormick, The Black Student Protest Movement at Rutgers (New Brunswick: Rutgers University Press, 1990).

8. "Slavery at Princeton," http://www.princeton.edu/mudd/news/faq/topics/slavery.shtml, accessed 6 November 2009.

9. See William Selden, Chapels of Princeton University: Their Historical and Religious Significance (Princeton: Office of Communications, 2005).

10. “A Negro at Princeton?” Princeton Alumni Weekly, 29 March 1935, page unknown.

11. "Minutes of the Board of Trustees," 25 September 1792, in the Historic Subject collection, Minorities at Princeton series, Box 1, Ethnic Diversity_-African Americans (1791-1991) file, Seely G. Mudd Manuscript Library, Princeton University, Princeton New Jersey. $131-135$

12. Timothy Tyson, Blood Done Sign My Name: A True Story (New York: Crown Press, 2005),

13. Melvin McCray, "Looking Forward: Reflections of Black Princeton Alumni," documentary video, 2006, http://alumni.princeton.edu/main/news/calendar/black_alumni_ conference/20091fdocumentary/, accessed 10 November 2009.

14. Matthew Anderson, Presbyterianism: Its Relation to the Negro (Philadelphia: The Sunshine Press, 1897), 168-169.

15. Arthur V. Bryan, The Mirror: A History of the Class of 1878, of Princeton College (Princeton: printed by Charles S. Robinson, 1878), 80-81. "A Race Trouble at Princeton College," Nashville American, 27 September 1876, page unknown.

16. Anderson, Presbyterianism, 175-176.

17. John M. Mulder, Woodrow Wilson: The Years of Preparation (Princeton: Princeton University Press, 1978), 137.

18. Woodrow Wilson to John Rodger Williams, September 2, 1904, Arthur Link, et al., eds., The Papers of Woodrow Wilson, Volume 15, 1903-1905 (Princeton, 1973), 463.

19. G. McArthur Sullivan to Woodrow Wilson, November 20, 1909, in the Historic Subject collection, Minorities at Princeton series, Box 1, Ethnic Diversity-African Americans (1791-1991) file, Seely G. Mudd Manuscript Library, Princeton University, Princeton New Jersey.

20. Secretary of Woodrow Wilson to G. McArthur Sullivan, December 6, 1909, in the Historic Subject collection, Minorities at Princeton series, Box 1, Ethnic Diversity-African Americans (1791-1991) file, Seely G. Mudd Manuscript Library, Princeton University, Princeton New Jersey. 


\section{Stefan M. Bradley}

21. William White (class of 1923), Princeton Alumni Weekly, 14 May 1948, in the Historic Subject collection, Minorities at Princeton series, Box 1, Ethnic Diversity-African Americans (1791-1991) file, Seely G. Mudd Manuscript Library, Princeton University, Princeton New Jersey.

22. Mark Bernstein, "A Princeton Pioneer: When Joseph Moss '51 Broke through the Color Line," Princeton Alumni Weekly, date unknown, in the Historic Subject collection, Minorities at Princeton series, Box 1, Ethnic Diversity-African Americans (1791-1991) file, Seely G. Mudd Manuscript Library, Princeton University, Princeton New Jersey.

23. Ibid.

24. "Looking Back: Reflections of Black Princeton Alumni," Princeton Today, Summer 1997, http://www.princeton-abpa.org/dynamic.asp?id=history, accessed 26 September 2011; Robert Schneller, Jr., Breaking the Color Barrier: The US Naval Academy's First Black Midshipmen and the Struggle for Racial Equality (New York: New York University Press, 2005), 156.

25. For information on the "Double V" campaign, see Paul Burstein, Discrimination, Jobs, and Politics: The Struggle for Equal Employment Opportunity in the United States since the New Deal (Chicago, University of Chicago Press1998); Richard Dalfiume, Desegregation of the U.S. Armed Forces: Fighting on Two Fronts, 1939-1953 (Columbia: University of Missouri Press, 1969); Lou Potter, Liberators: Fighting on Two Fronts in World War II (New York: Harcourt Press, 1992); Neil McMillen and Morton Sosa, ed., Remaking Dixie: The Impact of World War II on the American South (Jackson: University of Mississippi Press, 1997; Andrew Kersten, Race and War: The FEPC in the Midwest, 1941-1946 (Champaign: University of Illinois Press, 2000), Paula Pfeffer, A. Philip Randolph, Pioneer of the Civil Rights Movement (Baton Rouge: Louisiana State University Press, 1990); John D'Emilio, Lost Prophet: The Life and Times of Bayard Rustin (New York: Free Press, 2003); John Hope Franklin, “Their War and Mine," Journal of American History, vol. 77, no. 2 (Fall, 1990), 576-579.

26. "Negroes," Princeton Alumni Weekly, 29 March 1940, page unknown.

27. Ibid.

28. Alexander Leitsch, "Norman Thomas," A Princeton Companion (Princeton, 1978), http:// etcweb.princeton.edu/CampusWWW/Companion/thomas_norman.html, accessed January 12, 2011.

29. "Negroes," Princeton Alumni Weekly, 12 April 1940, page unknown.

30. "Ralph John Reiman '35," http://paw.princeton.edu/memorials/17/87/index.xml, accessed January 27, 2011.

31. "Democracy Begins at Home," Daily Princetonian, 31 July 1942, 2.

32. "White Supremacy at Princeton," Daily Princetonian, 30 September 1942, 1.

33. For comprehensive discussions of Jackie Robinson's experiences, see Arnold Rampersad, Jackie Robinson: A Biography (New York: Alfred A. Knopf Press, 1998) and Jules Tygiel, Baseball's Great Experiment: Jackie Robinson and His Legacy, expanded edition (New York: Vintage Press, 1997); for discussion regarding the desegregation of the armed forces see Dalfiume, Desegregation of the U.S. Armed Forces; Potter, Liberators; for summaries of Morgan v. Commonwealth and Shelley v. Kraemer see Joseph Menez and John R. Vile, Summaries of the Leading Cases on the Constitution (New York: Rowman \& Littlefield Publishers, 2010) and Joseph Tussman, ed., The Supreme Court on Racial Discrimination (New York: Oxford University Press, 1963).

34. Bernstein, “A Princeton Pioneer.” In 1895, the Reverend Irwin William Langston Roundtree became the first to receive a graduate degree (M.A.). It took another half century for a black student to achieve such success at the undergraduate level. "African Americans and Princeton University: A Brief History," http://www.princeton.edu/mudd/news/faq/topics/African_Americans.shtml, accessed November 14, 2010.

35. "Looking Back: Reflections of Black Princeton Alumni," Princeton Today, Summer 1997, http://www.princeton-abpa.org/dynamic.asp?id=history, accessed 26 September 2011.

36. Robert J. Rivers, "Sankofa: Looking Back As We Move Forward," Princeton Alumni Weekly, 16 July 2008, http://www.princeton.edu/ paw/web_exclusives/plus/plus_071608rivers. html, accessed January 27, 2011.

37. Ibid.

38. "Looking Back: Reflections of Black Princeton Alumni," Princeton Today, Summer 1997.

39. Bernstein, “A Princeton Pioneer." See http://www.princeton.edu/ paw/archive_new/ PAW05-06/14-0607/features jrmoss.html, accessed 23 December 2011.

40. "Dr. Charles T. Davis Shatters Precedent," Newark Herald, 3 July 1955, 1.

41. Douglas Martin, "Robert Goheen, Innovative Princeton President, Is Dead at 88," New York Times, 1 April 2008, http://www.nytimes.com/2008/04/01/nyregion/01 goheen.html, accessed 18 November 2008.

42. "Ivy Colleges Encourage Negro Applicants," Daily Princetonian 14 November 1963, 1.

43. For a discussion of the history of African Americans in Trenton see John Cumbler, A Social History of Economic Decline: Business, Politics and Work in Trenton (New Brunswick: Rutgers University Press, 1989), 149-150.

44. Jonathon Livingston, "Negro Admissions Stay Static," Daily Princetonian, 16 April 1963, 1. 
45. Mel Masuda, "Ivy Colleges Encourage Negro Applicants," Daily Princetonian, 14 November 1963,1 .

46. John Armstrong, "Group Promotes Segregation," Daily Princetonian, 13 March 1964, 1.

47. Department of Public Information, Princeton University, 16 August 1966, in the Historic Subject collection, Minorities at Princeton series, Box 1, Ethnic Diversity-African Americans (1791-1991) file, Seely G. Mudd Manuscript Library, Princeton University, Princeton New Jersey. video.

48. Melvin McCray, "Looking Forward: Reflections of Black Princeton Alumni," documentary

49. For discussions of student protest at Ivy League universities see, Bradley, Harlem vs. Columbia University; Jerry Avorn, ed., Up Against the Ivy Wall: A History of the Columbia Crisis, (New York: Atheneum, 1968); Roger Kahn, The Battle for Morningside Heights: Why Students Rebel (New York: William Morrow and Company, Inc. 1970); James Kunen, The Strawberry Statement: Notes from a College Revolutionary; Mark Rudd, Underground: My Life with SDS and the Weathermen (New York: William Morrow, 2009); Joanne Grant, Confrontation on Campus: The Columbia Pattern for the New Protest (New York: Signet Books, 1969); Glasker, Black Students in the Ivory Tower; Downs, Cornell '69; Sollors, et. al., Black at Harvard: A Documentary History of African-American Experience at Harvard and Radcliffe (New York: New York University Press, 1993); Lawrence Eichel, et. al., The Harvard Strike (Boston: Houghton Mifflin, 1970); Cushing Strout, Divided We Stand: Reflections on the Crisis at Cornell (New York: Doubleday, 1971); Laura Kalman, Yale Law School and the Sixties: Revolt and Reverberations (Chapel Hill: University of North Carolina Press, 2005).

50. For a more detailed discussion of black students' attempt to establish campus identities, see Bradley, Harlem vs. Columbia University; Downs, Cornell '69; William Exum, Paradoxes of Protest: Black Student Activism at a White University (Philadelphia: Temple University Press, 1985); Glasker, Black Students in the Ivy Tower; Joy Ann Williamson, Black Power on Campus; Richard McCormick, The Black Student Protest Movement at Rutgers.

51. "Drewry Gets Guidance Job at Princeton," Evening Times (Trenton), 20 March 1968, 1; "Nassau Post to Drewry," Trentonian, 20 March 1968, 1; "Princeton Placement Post Filled," Newark Herald, 20 March 1968, 1.

52. "Negro Pair Join Faculty," Philadelphia Inquirer, 3 October 1968, page unknown; "Princeton Gets Negroes to Teach Black Culture," Evening Bulletin (Philadelphia), 3 October 1968, page unknown; "Princeton Adopts 2 Negro Courses," Evening Bulletin (Philadelphia), 30 September 1968, page unknown; "Black Couple to Teach Black Courses at Princeton," Jet, 17 October 1968, 23. Princeton established a program for Black Studies in 1969.

53. "Both Sides Censured in Princeton Race Incident," New York Times, 2 November 1968, 16.

54. Gerald Horne, interview by author, 23 January 2010, email.

55. "Black Collegians," Princeton Alumni Weekly, 2 May 1967, in the Historic Subject collection, Minorities at Princeton series, Box 2, Ethnic Diversity-African American, Association of Black Collegians file, Seely G. Mudd Manuscript Library, Princeton University, Princeton, New Jersey.

56. "Department of Public Information," date unknown, in the Historic Subject collection, Minorities at Princeton series, Box 2, Ethnic Diversity - African American, Association of Black Collegians file, Seely G. Mudd Manuscript Library, Princeton University, Princeton, New Jersey.

57. "Second Negro Joins Student Aid Staff; ABC Sponsors Enrichment Program," date unknown, in the Historic Subject collection, Minorities at Princeton series, Box 2, Ethnic Diversity-African American, Association of Black Collegians file, Seely G. Mudd Manuscript Library, Princeton University, Princeton, New Jersey. 1-2.

58. Stephen Dreyfuss, "Osander Discloses Tripled Black Admission," Daily Princetonian, 11 April 1968, 1; "Department of Public Information," in the Historic Subject collection, Minorities at Princeton series, Box 2, Ethnic Diversity-African American, Association of Black Collegians file, Seely G. Mudd Manuscript Library, Princeton University, Princeton, New Jersey.

59. Jerome Karabel, The Chosen: The Hidden History of Admission and Exclusion at Harvard, Yale, and Princeton (Boston: Houghton Mifflin Company, 2005), 9.

60. "Association of Black Collegians Conference, 1967," in the Historic Subject collection, Minorities at Princeton series, Box 2, Ethnic Diversity-African American, Association of Black Collegians file, Seely G. Mudd Manuscript Library, Princeton University, Princeton, New Jersey.

61. "ABC to Boycott Tuesday," Daily Princetonian, 8 April 1968, 2.

62. Ibid.

63. Ibid., 1.

64. Francis Nesbitt, Race for Sanctions: African Americans against Apartheid, 1946-1994 (Bloomington: Indiana University Press, 2004), 60-68.

65. Press release of American Negro Leadership Conference on Africa, 5 September 1962, Peter Weiss collection, African Activist Archives, http://africanactivist.msu.edu/document_metadata. php? objectid=106, accessed 10 February 2009; "Recommendations for Action against Apartheid," ibid. 


\section{Stefan M. Bradley}

66. Donald Culverson, "The Politics of the Anti-Apartheid Movement in the United States, 1969-1986," Political Science Quarterly, Vol. 111, No. 1 (Spring, 1996), 134.

67. F.W. Lancaster and Lorraine Haricombe, "The Academic Boycott of South Africa: Symbolic Gesture or Effective Agent of Change?," Perspectives on the Professions, vol. 15, no. 1 (fall 1995), http://ethics.iit.edu/perspective/v15n1\%20perspective.pdf, accessed 6 February 2010.

68. Harry Edwards, Revolt of the Black Athlete (New York: Free Press, 1970), 55-56; 92-97. See also Amy Bass, Not the Triumph but the Struggle: The 1968 Olympics and the Making of the Black Athlete (Minneapolis: University of Minnesota Press, 2004).

69. Students at Cornell University also protested their school's ties to companies that operated in apartheid-South Africa. Downs, Cornell '69, 131-34.

70. Department of Public Information, Princeton University, 6 January 1969, 1.

71. Ibid.

72. Ibid. 1969.

73. "Malkiel Report" in Department of Public Information, Princeton University, 6 January

74. "Goheen Investment Statement," Department of Public Information, Princeton University, 4 March 1969, 2 p.m., in the Historic Subject collection, Minorities at Princeton series, Box 2, Ethnic Diversity-African American, Association of Black Collegians file, Seely G. Mudd Manuscript Library, Princeton University, Princeton, New Jersey.

75. Ibid.

76. "Princeton to End Credit in R.O.T.C.," New York Times, 4 March 1969, 29.

77. "South African Trade Views Outlined by Princeton," Chicago Tribune, March 1969, 7.

78. Rose DeWolf, Evening Bulletin (Philadelphia), 11 March 1969, 1.

79. Ibid.

80. Ibid.

81. DeWolf, Evening Bulletin, 13 March 1969, 1.

82. Ibid., 4.

83. "Black Students End Princeton Takeover," Trentonian, 12 March 1969, 1.

1.

84. "Princeton Sit-In Abandoned by Negro Students," Philadelphia Inquirer, 12 March 1969,

85. "Students Occupy Princeton Hall," New York Times, 12 March 1969, 30.

86. "Black Students End Princeton Takeover," 1-2.

87. "Negro Students Abandon Sit-In at Princeton Campus," Evening Bulletin, 12 March 1969, 1.

88. "Students Occupy Princeton Hall," 30.

89. "Long Winter for Nassau," Trentonian, 13 March 1969, 48.

90. "Negro Students Abandon Sit-In at Princeton Campus," 1.

91. Ibid.

92. "On the Campus," Princeton Alumni Weekly, 22 April 1969, 18.

93. At Columbia, the trustees and administration were extremely rigid and left students with little to no voice in decision-making matters. Other universities were able to learn from the result of shutting students (and sometimes faculty) out of university governance. Bradley, Harlem vs. Columbia University, 133-154.

94. Horne interview.

95. "Apartheid Protesters Arrested at Princeton,” New York Times, 24 May 1985, http://query. nytimes.com/gst/fullpage.html?res=9C04E4DC1639F937A15756C0A963948260, accessed 25 January 2009. 